7. Reprod. Fert. (1974) 36, 427-428

\title{
THE TIME OF ENTRY OF OVA INTO THE UTERUS OF THE EWE
}

\author{
P. J. HOLST \\ N.S.W. Department of Agriculture, \\ Agricultural Research Station, Condobolin, 2877, Australia
}

(Received 22nd August 1973)

Precise estimates for the time of entry of the ovum into the uterus from the oviduct are not available for the sheep. Data presented by Clark (1934), Lang (1969) and others suggest that the ovum enters the uterus between 60 and $96 \mathrm{hr}$ after the end of oestrus but the time of ovulation was not accurately assessed. In a study in which the time of ovulation was accurately determined, Holst \& Braden (1972) found that the ovum remains in the oviduct for at least $60 \mathrm{hr}$ after ovulation. The experiment described below was undertaken to determine the time and stage of segmentation at which ova entered the uterus.

Forty primiparous Border Leicester $\times$ Merino ewes and three vasectomized rams were placed in yards where continuous observation could be maintained. To facilitate the conduct of the experiment, observations were made at the second synchronized oestrus following withdrawal of progestagen pessaries (Repromap; Upjohn). When ewes were observed to be in oestrus, they were immediately removed from the flock and placed in a yard isolated from the rams. Four hours later, fertile rams were introduced and allowed to remain for the next $20 \mathrm{hr}$. After this time, ewes were teased hourly until the cessation of oestrus. The time of ovulation $( \pm 1 \mathrm{hr})$ was determined by repeated endoscopy (Holst \& Braden, 1972).

Ewes were subjected to laparotomy under general anaesthesia (pentobarbitone sodium) at a predetermined time after ovulation. Initially, this was $72 \mathrm{hr}$, then $68 \mathrm{hr}$ and finally $66 \mathrm{hr}$ after ovulation. In addition, three ewes were subjected to laparotomy at $60 \mathrm{hr}$ after ovulation to permit a comparison with the previous work of Holst \& Braden (1972).

The reproductive tract was exposed and the oviducts and surrounding mesosalpinx were sprayed with $2 \%$ Lignocaine to arrest the motility of the oviduct. Ligatures were then placed at the infundibulum and the uterotubal junction of each oviduct and bowel forceps were placed at the anterior end of the cervix. Following hysterectomy, the tracts were immediately placed on ice and were then transferred to a refrigerator where they were stored at $4^{\circ} \mathrm{C}$ for $2 \mathrm{hr}$.

The oviducts and uterus were subsequently dissected free of attachments, gently wiped with absorbent paper and the position of the ligature at the uterotubal junction was checked for accuracy of placement before the tract was segmented into oviducal and uterine portions. The uterine portion included the transitional zone between the isthmus and uterus. Each portion was flushed with $0.9 \% \mathrm{NaCl}$ solution and the resultant flushings were examined under a 
dissecting microscope for the presence of ova. Of the ova recovered from uterine flushings, eight which were fertilized (five at $72 \mathrm{hr}$, and three at $68 \mathrm{hr}$ ) were stained in $1 \%$ orcein for further examination under phase-contrast microscopy. Details of the location of the ova are presented in Table 1.

Table 1. The location of ova in the reproductive tract of the ewe on Days 2 and 3 after ovulation

\begin{tabular}{l|r|r|r|r|r}
\hline \multirow{3}{*}{ Portion of tract } & \multicolumn{5}{|c}{$\begin{array}{c}\text { No. of ova recovered at various times } \\
\text { after ovulation }(\mathrm{hr})\end{array}$} \\
\cline { 2 - 7 } & $60^{*}$ & 60 & 66 & 68 & 72 \\
\hline Oviduct & 24 & 3 & 1 & 2 & 1 \\
Uterus & 0 & 0 & 6 & 8 & 8 \\
\hline Total recovered $\dagger$ & 24 & 3 & 7 & 10 & 9 \\
\hline
\end{tabular}

* Holst \& Braden (1972).

† Ova recovery rate was $73 \%$.

Holst \& Braden (1972) concluded that the time at which $50 \%$ of ova pass into the isthmus was between 52 and $60 \mathrm{hr}$ after ovulation. The present experiment suggests that the majority of ova are present in the uterus $66 \mathrm{hr}$ after ovulation which is considerably earlier than was anticipated. The data also suggest that the time of entry of ova into the uterus is relatively precise compared with the movement of ova past the ampullary-isthmic junction into the isthmus.

Ova stained after recovery from the uterus at 68 or $72 \mathrm{hr}$ after ovulation were at the eight-cell stage of development.

The author wishes to thank $\mathrm{Mr} \mathrm{A}$. Kajons for his skilled technical assistance.

\section{REFERENCES}

GLARK, R. T. (1934) Studies on the physiology of reproduction in the sheep. 11. The cleavage stages of the ovum. Anat. Rec. 60, 135.

Holst, P. J. \& Braden, A. W. H. (1972) Ovum transport in the ewe. Aust. F. biol. Sci. 25, 167.

LANG, D. R. (1969) Transport of ova through the oviduct of Merino ewes. $\mathcal{N}$. Z. vet. J. 17, 200. 